\title{
VIRTUAL EDUCATIONAL ENVIRONMENT IN THE TRAINING OF A PROFESSIONALLY COMPETENT FOREIGN LANGUAGE TEACHER
}

\author{
Mira Kanbakova ${ }^{1}$, Mariana Petrova ${ }^{2}$ \\ ${ }^{1}$ E.A. Buketov Karaganda University, Karaganda, Kazakhstan \\ ${ }^{2}$ St. Cyril and St.Methodius University of Veliko Tarnovo, Bulgaria \\ ORCID ID: 0000-0003-1531-4312
}

\begin{abstract}
The article characterizes the basis of the notion of a virtual educational environment: its interpretations, specific features and criteria. It also provides justification in favor of the importance of this concept in pedagogical training as well as a set of drawbacks. The analysis of scientific works of foreign and domestic researchers within the framework of the topic is carried out. The purpose of this article is to analyze and reveal the foundations of virtual learning environments from the point of view of its significance for a competent and developed teacher of a foreign language.
\end{abstract}

\section{INTRODUCTION}

The concept of virtual environments has been well-known for the last decade at least [Alexandrov, 2012; Arsova, 2021A; Arsova, 2021B; Arsova, 2020; Diachok et al, 2020; Ivanchuk et al, 2020; Goletiani et al, 2021; Sushchenko et al, 2021; Valdmane et al, 2020]. However, there is still a need to specify the essence of it, therefore we are obligated to clarify the notion of virtual education environment. Essentially, a virtual educational environment, according to modern researchers, exists and develops in the telecommunication space and is understood as part of a complex information educational environment. The latter is a set of informational, educational, methodological, technical conditions implemented through information and communication means, aimed at the educational process and interconnected with its participants, in which their self-determination and productive selfrealization take place [Minina, 2016].

\section{DISCUSSION}

According to Wilson, 1996, virtual educational environment can be defined as a computer/technological environment, a relatively open system that provides communication and information exchange with other participants and teachers, and provides access to a wide range of assets and resources [Arslan \& Kaisy, 2013]

Rouse, 2011, claimed the following: "online educational environment is a set of teaching and learning tools designed to develop students' learning abilities using computers and the Internet in the learning process" [Arslan \& Kaisy, 2013: 59].

The Cambridge Dictionary, for instance, provides a very concise, to our mind, definition of the concept of a virtual learning environment: it is "a system for learning and teaching using the internet and special software" [Cambridge Dictionary, n.d.].

Following in A.Yu. Uvarov's footsteps, it can be stated that an online educational environment is an "open educational architecture" with mobile goals, content, methods and forms of organization consisting of three types of space: communication, information and physical. ICT should provide effective interaction between the teacher and students, as well as include optimal learning process management functions, have a user-friendly interface and support many didactic components. From a technological viewpoint, as per Weindorf-Sysoeva, "a virtual educational environment is an information space of interaction between participants in the educational process generated by information and communication technologies, including a complex of computer tools and 
technologies that allows managing the content of the educational environment and communication of participants" [Weindorf-Sysoeva, 2012: 89].

The word "virtual" is a word of a Latin origin ("virtualis" is "possible"). When trying to determne the interpretation of this concept, a number of main characteristics of virtuality are highlighted. The probabilistic nature of the object's manifestation is emphasized: virtual - "nonexistent, but possible" [...], "possible" [...], "...", "that which is put into the supersensible essence and is able to be realized" [...]. The immateriality of the object is also emphasized: virtual is "an immaterial kind of being of objective entities or subject images, opposite to the material being of discrete things and phenomena in space and time" [...]. Another characteristic that stands out is the following: "this is the existence of certain conditions for the manifestation of the object", following further, it is apparent that virtual is "one that can or should manifest under certain conditions, but does not exist in reality" [...]. In addition to what has been stated above, the possibility of manifestation with the help of information and communication technologies is noted: virtual is "created on a computer screen, reproduced by computer means" [...]. Thus, a logical conclusion can be drawn: "virtuality is the possibility of manifestation of an object or phenomenon in certain conditions, reproduced by means of ICT" [Minina, 2016: 72].

In modern pedagogy there is no single interpretation of the concept of "virtual educational environment", which could be viewed as generally accepted. However, a number of similar concepts are used (according to Noskova, Sidorenko, Privalov, Weindorf-Sysoeva, Kozina):

- high-technology virtual network educational environment;

- educational information space;

- information and educational environment of the university;

- electronic educational environment;

- virtual educational environment [Minina, 2016: 73].

Notwithstanding the lack of unified approaches in determining the structure of the virtual educational environment, we can draw our attention to the relations of its components. These components might include personal educational environments of students, personal environments for teachers, global and local networks, learning management systems (LMS)" [Starichenko \& Yavich, 2017].

The ongoing discourse has been supported by P. Dillenbourg who argued in the following manner: "Does «the virtual educational environment» refer to any educational website? No. However, like many buzzwords, some authors use it in a very broad sense, including, let us say, websites that simply include static web pages. Is «the virtual educational environment» limited to systems that include some 3D or virtual reality 3D technologies? No. Some environments include less intricate interfaces, namely text. Between these overly general and overly specific definitions, there are a number of conditions that differ by criteria ..." [Dillenbourg, 2000].

Additionally, the author also lists the criteria for the virtual educational environment:

1. It is a designed information space, because any website is a built information space.

2. It is a social space. As an example, we can hardly call a book a learning environment, however, reading a book during a seminar, discussing it with other students - all of this does constitute a learning environment. By analogy, a set of web pages is not a virtual educational environment per se, simply because it might exist without social interaction based on information. This interaction can be synchronous (for example, chat messaging) and asynchronous (for instance, email, forums), oneon-one communication or communication with many, through text or via audio or video.

3. It is represented explicitly. Virtual educational spaces can be presented in different formats: from simple, merely combining of text to graphically sophisticated ones. Nevertheless, the question is not about the representation of a virtual educational environment itself, but about how students actually work with it and the forms of its representation. In this regard, it becomes quite clear that a pleasant kind of presentation of the virtual educational environment causes a positive attitude to it. Although, in fact, certainly like all external motivational factors, its impact on students often does not last very long. But ideas about virtual spaces can influence the learning process in addition to motivational aspects. 
4. Students not only actively participate in the work with online educational systems, but are also its active creators. Students are not limited to the consumption of web information, they become producers of the latter. Often students are engaged in various written tasks, such as preparation of research reports, creation of newspapers, etc.

5. It is not limited to distance learning. Learning using virtual educational environments is often associated with distance education, but in practice it is also widely used as a supporting tool to the traditional form of learning.

6. It combines several tools that support many functions: those for information, communication, collaboration, learning, management. Integration is also present when the teacher creates a page for the course, which includes key pointers, chat, quizzes, etc.

7. It intersects with the physical environment. Any online learning environment not only integrates various software tools, but also does integrate various physical tools, however, of course, there are some "clean" virtual environments designed for educational programs that are entirely remote: students never go to school and never meet each other. But, traditionally, most online learning systems include:

- a variety of "non-computer" learning resources: a number of management tools, textbooks;

- various types of interaction not mediated by a computer: personal discussion between students, lectures with a teacher, group discussions...;

- various types of non-computer-based activities: excursions, role-playing games ... [Dillenbourg, 2000].

Also, the concept of computer-mediated learning environments can be considered a dynamic concept, due to its features and capabilities, as well as its constant development of digital technologies and, ultimately, the importance that such environments have in learning processes [Alves et al., 2017].

The factors of the virtual educational environment, as Weindorf-Sysoeva has stated, which ensure the effectiveness of communication within the educational environments existing in the virtual space, are:

- interactivity: availability of feedback, as well as a variety of opportunities to provide it in various ways;

- linguistic diversity (means of expression);

- personal orientation;

- synchronicity of communication [Weindorf-Sysoeva, 2014].

The use of technology-based learning environments provides a lot of benefits. An instance: a teacher has an opportunity to track whether students participate in the learning process, whether they send completed assignments and provide feedback. The ability to communicate online likewise enables setting up students to work together and communicate between the teacher and students. In addition, any necessary information, such as: past exam papers, schedule, information from the administration can be found in one accessible reliable place and spread among learners.

A very important advantage is that the virtual learning environments allow teachers to save time that could previously may have been used quite irrationally on printing and copying the necessary handout materials, distributing them to students in the classroom, etc. The time for preparing classes and searching for the necessary resources and materials is reduced when using a virtual learning environment. The main advantage of the latter is moreover that it becomes possible to present information in various forms, e.g., objects from different perspectives or angles, or at different scales, via animated diagrams, flowcharts: the list goes on.

In terms of the advantages of using virtual environments in education, we cannot but pay attention to the drawbacks of them and, unfortunately, there are a few. The disadvantage of online environments can be considered their supposed insufficient effectiveness in teaching basic simple skills. The material presented in the framework of the virtually-represented environments is merely an "abstract representation of real things". Thus, training with the use of online environments may not have the same impact as training in the traditional "face-to-face" format. Virtual learning medium 
are not in any way more sufficiently interactive and "tangible", so to speak, than traditional forms of learning, where real interaction takes place [Arslan \& Kaisy, 2013].

Dillenbourg, who was been mentioned before, expressed a very curious point of view. $\mathrm{He}$ strongly believed that multimedia tools do not have internal efficiency, but simply offer opportunities. Since virtual learning systems represent a new generation of computer-based educational systems, it is worth analyzing whether computer-based learning is more effective than learning in a traditional classroom. The history of educational technologies shows that every new technology, such as television, computers, multimedia, Internet, causes naive expectations about the internal effects of these technologies. It has been noticed that the effectiveness of educational programs often depends on the pedagogical context in which they are used. It has been observed, Dillenbourg supposed, that the way students navigate, even when using simple hypertexts, is greatly influenced by the tasks that teachers set them. Thus, the effectiveness of the training course depends on the pedagogical context of use: the pedagogical scenario in which the textbook is integrated, the degree of teacher's participation, time frame, technical support, etc. The very same difficulty, however, occurs in all reforms of educational systems and does not specifically apply to technology, the author concluded [Dillenbourg, 2000: 14-15]. We agree to the fullest with his point of view, because the efficacy of using any set of tools, methods and technologies in teaching, first of all, depends on how teachers use these tools, methods and technologies, how competently and effectively they are implemented in teaching. One cannot only rely entirely on the potential of third-party tools in the educational context, hence we must first of all place the responsibility on teachers.

Since the beginning of the transformation of education and its shift to computer-mediated and virtualized forms, it has been necessary to know how to use ICT in the process of teaching and be able to use these tools in education, because learning in new technology-supported conditions also requires a slightly different role from the teacher. "The teacher, as a variable of the educational process, should become familiar with educational technology in order to generate learning experiences that contribute to the development of thinking skills and their application" [Aguilar \& Ornelas, 2017].

Chickering \& Gamson have derived seven principles of effective learning that are traditionally used in face-to-face learning:

1. Encourage contacts between students and teachers.

2. Develop reciprocity and cooperation between students.

3. Encourage active learning.

4. Give prompt feedback.

5. Give particular attention to the sufficient time for completing a task.

6. Communicate high expectations.

7. Respect diverse talents and ways of learning [Bigatel et al., 2012].

"Since the publication of this article in 1987, these principles have been applied to an online learning environment to varying degrees" [Bigatel et al., 2012: 60]. This is not at all surprising, because the learning process is still unchanged - only the tools and certain techniques used change. These seven principles of effective learning listed above can also be used when using technology in teaching. And if the quality of education has been improved through the use of these seven principles in the traditional format of education, then their application in the online environment is also quite justified and, in fact, mandatory.

When using the virtual learning systems, the following is required from the teacher:

- organizing events and providing educational materials based on the psychological and pedagogical characteristics of students;

- controlling, monitoring and diagnosing educational activities in such a way that the mode communication is chosen given the information and communication technologies;

- organizing activities, selecting educational materials, monitoring and diagnosing students' activities given the information and communication technologies, taking into account the psychological and pedagogical characteristics of students; 
- organizing activities based on educational material, monitoring and diagnosing educational activities, implementing the stage of reflection on the results of students' educational activities [Starichenko \& Yavich, 2017].

Online competency-based learning helps both students and teachers to achieve educational goals and achieve them through interaction, flexibility and accessibility. Educational technology manifests and develops in connection with advanced teaching technology and technical accounting [Catalina et al., 2021].

Also, taking into account the fact that education has undergone significant changes, that the role of the teacher has also changed, and additionally that the use of technology-based educational environments likewise leaves its imprint on the specifics of training, we understand that the set of competences required from the teacher could also be reviewed. Several competences a teacher may need in online learning are:

- Competences which relate to "Active Learning": formulation of explanations/solutions, practical exercises, materials created by students, group tasks and projects, as well as peer assessment.

- Competences designated as "Administration/Leadership": considering the role of the teacher as the head of the teaching and learning process, manifesting of leadership, control, transparent and reasonable evaluation policy are necessary.

- Competences under the umbrella notions of "Active teaching/Response" refers to the role of the teacher as a "link" or a "mediator" between the student and the learning system. Within the framework of this competence, the teacher requires sensitivity, high-quality feedback and a caring approach to students in order to support the progress of students.

It is impossible not to mention the "technological" competence. The category of this competence is usually considered as the need for proper training of the instructor with the help of a technological training system and the subsequent confidence of the instructor in these technologies" [Bigatel et al., 2012].

\section{CONCLUSIONS}

As Philipsen and Tondeur have stated, teachers with previous work experience at any level of education should be well informed about the growth of knowledge in various fields, and need to constantly improve their qualifications and pursue professional development. Professional development essentially, is "the process whereby people's professionalism may be considered to be enhanced, with a degree of permanence that exceeds transitoriness". Developing teacher's proficiency itself then increases teacher's knowledge and skills and therefore influences their views and beliefs, teachers then use those to improve their learning and their approach to pedagogy. Ultimately, student learning also increases. It has been alleged that teachers who shift from traditional face-to-face to virtual or blended learning understand that this process requires "more than just posting a course online": "participation in online learning influences their perceptions and perceptions of learning (...) and transforms the pedagogical roles of teachers (...)." This goes to show that teaching through virtual media is different to teaching in the traditional classroom. "Therefore, being a good teacher in a personal environment does not mean that it will automatically be the same in an online environment (...)". Teaching online and the process of enhancing teaching proficiency requires "the continual investigation of effective pedagogical practices and teaching possibilities, as technology will continue to evolve [Philipsen et al., 2019].

Despite the occurring thoughts that a virtual educational environment simply acts as a supporting tool in any type of teaching / learning process, in reality it is not quite true and the role of online learning environments within developing of teachers' competences is indeed larger than we might suppose. A virtual learning space can act as a brilliant tool for providing feedback, distributing crucial information to students, track and monitor their achievements and is simply convenient to use. However, we realize that in order to teach efficiently using computer-mediated learning systems, we must continually pursue professional development as active teachers and that goes far beyond learning how to adequately use virtual educational environments alone. It touches upon one's new understanding of the core of teaching practice, its possibilities, the role of a teacher, one's beliefs and 
views, at times in a wider context which inevitably leads to a glimpse of crucial awareness and a further broader development of a teacher.

\section{REFERENCES:}

Aguilar, A., Ornelas, D. (2017). Teaching Competences in Higher Education Virtual Learning Environments. Universidad Autónoma De Chihuahua. Vol. 6, pp. 1317-1329.

Alexandrov M.O. One approach for the realization of an online poker game - funpoker. Proceedings of IX International scientific conference "Science and Education", Kemerovo State University, Belovo Institute (branch), March 28-29, 2012, Belovo, Russia. Vol.1., pp. 124-127

Alves P., Miranda L., Morais C. (2017). The Influence of Virtual Learning Environments in Students' Performance. Universal Journal of Educational Research. Vol. 5, pp. 517-527.

Arslan F., \& Kaisy F. (2013). Virtual learning environments. Journal of Teaching and Education. Vol 2, pp. 57-65.

Arsova, D. (2021). The role of e-books in the digitalisation process in primary school. "Innovations in technology and education": proceedings of XIV International scientific conference "Innovations in technology and education", 26 march 2021 г.: Kuzbass State Technical University, Belovo, Russia; 2021. - vol. 3., pp. 53-58 (in BG)

Arsova, D. (2021). Skills and competencies of the new generation of students to work with digital devices // "Innovations in technology and education": proceedings of XIV International scientific conference "Innovations in technology and education", 26 march 2021 г.: Kuzbass State Technical University, Belovo, Russia; 2021. - vol. 3., pp. 59-66 (in BG)

Arsova, D. (2020). Developing of the elementary school students' skills in a digital world // "Innovations in technology and education": proceedings of XIII International scientific conference "Innovations in technology and education", 26 march 2020 г.: Kuzbass State Technical University, Belovo, Russia; 2020. - vol. 4., pp. 55-60. ISBN 978-5-00137-065-9

Bigatel P.M., Kennan S., May J., Ragan L.C., Redmond B.F. (2012). The Identification of Competencies for Online Teaching success. The Pennsylvania State University. Journal of Asynchronous Learning Networks. Vol. 16, pp. 59-77.

Bondarenko, N., Rozdymakha, Y., Oderiy, L., Rozdymakha, A., Arsova, D. (2021). Education Of Moral Culture Of Student Youth In The Conditions Of Polycultural Space. PEDAGOGIKAPEDAGOGY. Volume 93, Issue 7, Page 978-992. https://doi.org/10.53656/ped2021-7.09

Cambridge University Press. (n.d.). Retrieved October 30, 2021 from https://dictionary.cambridge.org/us/dictionary/english/virtual-learning-environment

Catalina G., Eduardo C., Mallillin, D., Mallillin, J., Mallillin, L.L., Regilito L. (2021). Competency Based-Learning and Quality Education in the New Normal Modality of Teaching.

Diachok, N., Chernukha, N., Tokaruk, L., Udovenko, L., Petrova, M. (2020). Practical-oriented concept as a principle of professional education of the future professionals. International Journal of Higher Education, 9(4), August 2020, 272-282.https://doi.org/10.5430/ijhe.v9n4p272

Dillenbourg P. (2000). Virtual learning environments. EUN CONFERENCE 2000: «Learning in the new Millenium: Building new education strategies for schools». University of Geneva.

Goletiani, K., Mushkudiani, Z., Gulua, E., Janelidze, N. (2021). Difficulties in managing diversity in Georgian educational organizations. Access to science, business, innovation in digital economy, ACCESS Press, 2(2): 123-137. https://doi.org/10.46656/access.2021.2.2(1) 
Ivanchuk, S., Voznik,A., Dronova, O., Girenko, N., Arsova, D. (2020). Preparation of Future Preschool Education Specialists for the Use of Modern Educational Technologies. International Journal of Higher Education, Vol. 9, No. 5, June 2020, p.28-35, doi:10.5430/ijhe.v9n5p28 URL: https://doi.org/10.5430/ijhe.v9n5p28

Minina A.M. (2016). Opredelenie virtual'noj obrazovatel'noj sredy: Kompleksnyj podkhod [Definition of a virtual educational environment: an integrated approach]. Pedagogicheskoe Obrazovanie v Rossii - Pedagogical education in Russia. № 6, 71-76 [in Russian].

Pareja R., Philipsen, B., Tondeur, J. (2019). Improving teacher professional development for online and blended learning: a systematic meta-aggregative review. Educational Technology Research and Development.

Starichenko B., Yavich R. (2017). Design of Education Methods in Virtual Environment. Journal of Education and Training Studies. Vol. 5, pp. 176-186.

Sushchenko, O., Akhmedova, O., Stryzhak, O. (2021). The use of interactive training technologies in teaching academic disciplines for students of tourism specialities. Access to science, business, innovation in digital economy, ACCESS Press, 2(1): 28-39. https://doi.org/10.46656/access.2021.2.1(3)

Valdmane, L., Zarina, S., Iliško, D., Badjanova, J., Petrova, M. (2020). Empowering of digital and media literacy of primary school teachers in Latvia. Edulearn20,12th annual International Conference on Education and New Learning Technologies, 6th - 7th of July, 2020, https://iated.org/edulearn/; Proceedings of EDULEARN20 Conference 6th-7th July 2020, ISSN: 2340-1117, pp.4022-4029, DOI: 10.21125/edulearn.2020.1087

Weindorf-Sysoeva M.E. (2012). Virtual'naya obrazovatel'naya sreda kak neot'emlemy'j komponent sovremennoj sistemy obrazovaniya [Virtual educational environment as an integral component of the modern education system]. Vestnik Yuzhno-Ural'skogo gosudarstvennogo universiteta. Seriya: Obrazovanie. Pedagogicheskie nauki - Bulletin of the South Ural State University. Series: Education. Pedagogical sciences. 14 (273), 86-91 [in Russian]. 